\title{
PROBLEMATIKA PERCERAIAN MASYARAKAT KABUPATEN BONE DALAM TINJAUAN EKONOMI SYARIAH
}

\section{THE PROBLEMS OF DIVORCE SOSIETY BONE REGENCY IN ECONOMY SHARIAH PERSFECTIVE}

\author{
Sitti Nikmah Marzuki \\ Sekolah Tinggi Agama Islam Negeri Watampone \\ Jl. Hos Cokroaminoto \\ Email:nur_niki@yahoo.co.id \\ Hukmiah Husain \\ Sekolah Tinggi Agama Islam Negeri Watampone \\ Jl. Hos Cokroaminoto \\ Email: hukmiah_husain@yahoo.co.id \\ Uswatun Hasanah \\ Sekolah Tinggi Agama Islam Negeri Watampone \\ Jl. Hos Cokroaminoto \\ Email: uswah_intan@yahoo.com
}

Naskah diterima tanggal 9 September 2016. Naskah direvisi tanggal 19 Oktober 2016. Naskah disetujui tanggal 3 November 2016.

\begin{abstract}
Abstrak
Perkawinan adalah ikatan yang suci antara laki-laki dan perempuan dalam suatu rumah tangga. Melalui perkawinan dua insan yang berbeda itu, mereka disatukan dengan segala kelebihan dan kekurangan masing-masing. Namun harmonisasi keluarga terganggu oleh berbagai masalah rumah tangga yang kemudian berujung pada perceraian. Dalam penelitian ini akan dikaji mengenai faktor penyebab dari tingginya angka perceraiaan yang terjadi di Kabupaten Bone Sulawesi Selatan dan dampak setelah perceraian dan pengaruh problema ekonomi terhadap tingkat perceraian Kabupaten Bone mengenai masalah perceraian dan solusi menekan peningkatan jumlah perceraian di Kabupaten Bone dalam persfektif ekonomi syariah. Metode kualitatif di terapkan dalam penelitian ini dengan menggunakan beberapa instrument yakni observasi dan wawancara. Hasil penelitian menunjukkan bahwa perceraian terjadi karena beberapa faktor di antaranya faktor moral dan faktor meninggalkan. Diantara dampak dari percereaian yang terjadi adalah dampak psikologi, ekonomi, sosial. Sebagai solusi untuk menekan jumlah perceraian semua pihak akan berperan penting dalam pembinaan dan pemahaman ilmu-ilmu keagamaan, pengetahuan perceraian dan dampak yang timbul setelah perceraian dan memberikan syarat kemapanan ekonomi untuk calon pengantin agar mampu menekan jumlah perceraian karena motif ekonomi.
\end{abstract}

Kata Kunci: perceraian, ekonomi syariah, pernikahan, Watampone.

\begin{abstract}
Marriage is a sacred bond between men and women in a household. Through marriage united two different beings, with all the advantages and disadvantages of each. But family harmony disrupted by various domestic problems which then leads to divorce. In this study will examine the causal factors of the high divorce rate that occurred in Bone regency of South Sulawesi and the impact after the divorce and the effect of problems in the economy towards the divorce rate Bone Regency on the issue of divorce and Solutions suppress the increase in the number of divorces in Bone regency in perspective Islamic economics. Qualitative methods applied in this study by using several instruments of observations and interviews. The results showed that the divorce occurred because of several factors among which moral factors and the factors left. And provide psychological impact, economic, social. As a solution to reduce the number of divorces that all parties will play an important role in the development and understanding of the religious sciences, knowledge divorce
\end{abstract}


and impacts arising after divorce and economic establishment precondition for the bride and groom to be able menakan number of divorces due to economic motives.

Keywords: divorce, islamic economic, merrienge, Watampone.

\section{PENDAHULUAN}

$\mathrm{P}$ erkawinan adalah ikatan yang suci antara laki-laki dan perempuan dalam suatu rumah tangga. Melalui perkawinan dua insan yang berbeda disatukan, dengan segala kelebihan dan kekurangan masing-masing. Pada Zaman Jahiliyah, yang populer pada saat itu adalah, ketika suami bebas memadu istrinya dengan perempun lain tanpa batas. Suami bisa mentalak dan rujuk kembali sesuai kemauannya, bahkan ia bisa mentalak dan mempersulit perempuan tersebut sehingga ia tidak bisa menikah lagi selamanya (Abdul Aal, 2006: 1819). Pada dasarnya, kehidupan rumah tangga harus didasari oleh mawaddah, rahmah, dan cinta kasih. Pernikahan atau perkawinan merupakan perilaku sakral yang termaktub dalam seluruh ajaran agama. Dengan pernikahan diharapkan akan menciptakan pergaulan laki-laki dan perempuan menjadi terhormat, interaksi hidup berumah tangga dalam suasana damai, tenteram, dan rasa kasih sayang antara anggota keluarga, yang semuanya bermuara pada harmonisasi keluarga (Al-Athar, 2000: 5 dan Basyir, 1995: 1).

Namun fakta yang berkembang, harmonisasi keluarga terganggu oleh berbagai masalah rumah tangga yang kemudian berujung pada perceraian. Namun perlu dipahami bahwa perceraian merupakan jalan alternatif terakhir (pintu darurat) yang dapat dilalui oleh suami istri bila ikatan perkawinan (rumah tangga) tidak dapat dipertahankan keutuhan dan kelanjutannya. Sifat alternatif terakhir dimaksud, berarti sudah ditempuh berbagai cara dan tehnik untuk mencari kedamaian di antara kedua belah pihak, baik melalui hakam (arbitrator) dari kedua belah pihak maupun langkah-langkah dan teknik yang diajarkan oleh Alquran dan Hadis (Ali, 2007: 73).

Di Kabupaten Bone angka perceraian semakin meningkat dari tahun ke tahun, dari data Pengadilan Agama Kabupaten Watampone yang penulis himpun di PA Watampone Kabupaten Bone data bulan Maret 2015, terdapat 90 kasus perceraian dengan berbagai alasan. Kasus yang banyak terjadi adalah kasus gugat cerai dan cerai talak dengan alasan ekonomi keluarga, perselingkuhan, dan pernikahan di usia muda (Wawancara Jamaluddin, Panitera Pegadilan Agama, 15/03/2015).

Penelitian ini diharapkan mampu menekan jumlah perceraian yang bermotif ekonomi dengan memberikan aturan yang lebih ketat terhadap syarat perkawinan, bukan hanya syarat umur tetapi juga syarat kemampanan ekonomi. Berdasarkan masalah tersebut di atas, penulis mengemukakan beberapa rumusan masalah yang perlu di bahas yakni: Bagaimana faktor penyebab dari tingginya angka perceraiaan yang terjadi di Kabupaten Bone Sulawesi Selatan, dan dampak setelah perceraian, serta bagaimana pengaruh problema ekonomi terhadap tingkat perceraian Kabupaten Bone mengenai masalah peceraian dan solusi menekan peningkatan jumlah perceraian di Kabupaten Bone dalam perspektif ekonomi syariah?

\section{Tinjauan Pustaka}

Pernikahan merupakan akad syar'i yang dapat menghalalkan hubungan seksual antara dua jenis. (Ibrahim, 2009: 988). Islam memerintahkan untuk melaksanakan pernikahan jika pernikahan itu memberi pengaruh positif bagi setiap pribadi yang melaksanakan, bagi masyarakat, bagi manusia seluruhnya. Di antara hikmah pernikahan adalah sebagai berikut:

1) Pada dasarnya gairah seks merupakan dorongan yang paling kuat dan mendesak, yang mendorong seseorang untuk memenuhinya, jika tidak menemukan cara mengatasinya maka akan berpengaruh buruk pada seseorang. Dengan demikian pernikahan merupakan sebaik-baik solusi dalam mengatasi gairah seksual tersebut, yang memberi ketenangan pada anggota badan, dan menenangkan nafsu dari gejolak, dan menundukkan pandangan dari hal-hal yang diharamkan, dan memberi ketenangan pada perasaan kepada apa yang telah dihalalkan oleh Allah.

2) Pernikahan merupakan jalan terbaik dalam melahirkan generasi, memperbanyak keturunan, dan melanjutkan kehidupan dengan menjaga nasab yang kelak akan dibanggakan oleh Rasulullah di hari kemudian.

3) Memunculkan rasa keibuan dan kebapakan dengan memperhatikan pertumbuhan dan 
perkembangan anak, sehingga menumbuhkan perhatian dan rasa kasih sayang.

4) Membagi tanggung jawab dalam mengatur rumah tangga, sebagaimana pembagian pekerjaan di luar rumah, dengan membatasi tanggung jawab dari masing-masing laki-laki dan perempuan. Perempuan (istri) bertugas memelihara dan mengatur rumah, mendidik anak-anak, menjadikan rumah sebagai tempat istirahat yang nyaman bagi suami. Begitu pula tugas untuk suami memiliki tanggung jawab memenuhi kebutuhan anggota keluarganya dari harta dan nafkah.

5) Buah dari hubungan pernikahan dari ikatan keluarga ini yaitu, menguatkan tali cinta antara anggota keluarga dan memperkuat hubungan sosial, karena masyarakat yang terikat cinta maka masyarakat tersebut akan merasakan kebahagiaan (Sabiq, t.th: 8).

Perceraian adalah salah satu perbuatan yang dibenci oleh Allah, namun pada berbagai kondisi hal tersebut dibolehkan. Bentuk-bentuk Perceraian dalam Islam yaitu talak yang melepas ikatan talak berasal dari kata ithlaq yang berarti melepaskan atau meninggalkan (Kamal, 2007: 230). Dalam terminologi syariat, talak berarti memutuskan atau membatalkan ikatan pernikahan, baik pemutusan itu terjadi pada masa kini (jika talak itu berupa talak bain) maupun pada masa mendatang, yakni setelah iddah (jika talak berupa talak raji) dengan menggunakan lafaz tertentu.

Menurut Al Jaziri dalam kitabnya al figh alal madzahibil arbaiah memberi definisi, talak adalah menghilangkan ikatan perkawinan atau mengurangi pelepasan ikatannya dengan mempergunakan kata-kata tertentu. Sedangkan menurut As-Sayid Sabiq dalam kitab fiqhus sunnah memberikan definisi talak adalah melepas tali perkawinan dan mengakhiri hubungan suami istri. Abu Zakaria al Anshari dalam kitab fathul wahab mendefinisikan, talak adalah melepas tali akad nikah dengan kata talak dan semacamnya. Menurut Imam Nawawi dalam bukunya Tahzib, talak adalah tindakan orang terkuasai terhadap suami yang terjadi tanpa sebab kemudian memutus nikah (Khon, 2009: 255).

Hukum-hukum talak adalah sebagai berikut:a) Wajib jika terjadi konflik antar pasangan suami-istri, hakim menugaskan mediator dua orang mediator untuk menilai situasi konflik tersebut. Lalu, kedua mediator itu merekomendasikan bahwa sepasang suami-istri tersebut harus bercerai. Maka suami harus menceraikan istrinya. b) Sunnah seorang suami dianjurkan untuk melakukan talak dalam kondisi ketika istrinya kerap tidak menjalankan ibadah-ibadah wajib, seperti shalat wajib, serta tidak ada kemungkinan memaksa istrinya itu melakukan kewajiban-kewajiban tersebut. Talak juga sunnah dilakukan ketika istri tidak bisa menjaga diri dari perbuatan-perbuatan maksiat. c) Mubah, talak boleh dilakukan dalam kondisi ketika suami memiliki istri yang buruk perangainya, kasar tingkah lakunya, atau tidak bisa diharapkan menjadi partner yang ideal guna mencapai tujuantujuan pernikahan. Makruh bila dilakukan tanpa alasan yang kuat atau ketika hubungan suami-istri baik-baik saja. d) Haram apabila seorang istri di ceraikan dalam keadaan haid, atau keadaan suci dalam keadaan ketika ia telah disetubuhi di dalam masa suci tersebut (Kamal, 2007: 236).

Kehidupan rumah tangga suamilah pimpinan rumah tangga dan penanggung jawabnya. Dialah yang pembayar mahar dan pemberi nafkah kepada istrinya, sehingga tegaknya rumah tangga praktis dibebankan di pundaknya. Karena itu, wajar jika hancurnya rumah tangga yang paling dirugikan adalah dirinya, karena dialah yang telah berkorban dengan semua yang dimiliki untuk membina rumah tangga selama ini (Qardhawi, 2005: 235). Di samping itu, menurut Muhammad bin Ibrahim bahwa hak talak hanya dimiliki oleh suami, karena dialah yang berusaha mempertahankan hubungan suami istri dan memberi nafkah untuknya, serta lebih sabar dan berpikir panjang dengan akalnya dan tidak mendahulukan perasaannya (Ibrahim, 2009: 1024).

Konsep ekonomi sebagai suatu ilmu yang mempelajari perilaku manusia dalam usaha untuk memenuhi kebutuhan dengan alat pemenuhan kebutuhan yang terbatas di dalam kerangka syariah. Ilmu yang mempelajari perilaku seorang muslim dalam suatu masyarakat Islam yang dibingkai dengan syariah. Definisi tersebut mengandung kelemahan karena menghasilkan konsep yang tidak kompetibel dan tidak universal. Karena dari definisi tersebut mendorong seseorang terperangkap dalam keputusan yang apriori (apriory judgement), benar atau salah tetap harus diterima (Yuliadi, 2006: 6).

Para pemikir ekonomi Islam berbeda pendapat dalam memberikan kategorisasi terhadap prinsip-prinsip ekonomi Islam. Menurut Khurshid Ahmad menjelaskan dan mengkategorisasi prinsipprinsip ekonomi Islam pada: Prinsip tauhid, rubbiyyah, khilafah, dan tazkiyah (Kara, 2005: 37-38). 
Membicarakan tentang masalah ekonomi Islam, berarti bagi seorang muslim akan siap menerima kenyataan bahwa di dalamnya terdapat kaidahkaidah moral yang dijiwai dari semangat Alquran dan Sunah Rasulullah saw, dimana keduanya mencerminkan jiwa dari setiap kebaikan dan beribadah.

\section{METODE PENELITIAN}

Jenis penelitian ini adalah penelitian lapangan, kegiatan penelitian yang dilakukan di lingkungan masyarakat Kabupaten Bone dan Pengadilan Agama Kelas II B Kabupaten Bone. Jenis data yang di gunakan berupa data primer dan data sekunder yang diperoleh dari beberapa pihak sebagai informan yakni; Pihak yang melakukan perceraian, Pihak Pengadilan Agama Watampone, tokoh masyarakat, Pihak Kantor Urusan Agama Kabupaten Bone. Instrumen yang di gunakan adalah lembar observasi, panduan wawancara, dan dokumentasi yang berkaitan dengan penelitian. Data yang diperoleh kemudian dianalisis secara deskriptif.

\section{PEMBAHASAN}

Berdasarkan hasil penelitian yang penulis lakukan, maka sejak bulan Januari hingga bulan September 2015, terjadi kasus perceraian di Kabupaten Bone yang sangat signifikan. Data yang penulis peroleh di Pengadilan Agama Watampone dapat dilihat berikut ini:

Tabel 1

Jumlah Perceraian di Kabupaten Bone pada Pengadilan Agama Watampone

\begin{tabular}{|c|c|c|c|c|c|c|c|}
\hline \multirow[b]{2}{*}{ No } & \multirow[b]{2}{*}{ Bulan } & \multirow[b]{2}{*}{ Tahun } & \multicolumn{4}{|c|}{ Faktor penyebab } & \multirow[b]{2}{*}{ Jumlah kasus } \\
\hline & & & Moral & Meninggalkan & Menyakiti & Terus menerus & \\
\hline 1 & Oktober & 2014 & 14 & 25 & 7 & 28 & 80 \\
\hline 2 & Nopember & 2014 & 13 & 36 & 7 & 21 & 83 \\
\hline 3 & Desember & 2014 & 11 & 35 & 3 & 19 & 78 \\
\hline 4 & Januari & 2015 & 28 & 43 & 6 & 41 & 122 \\
\hline 5 & Februari & 2015 & 32 & 33 & 7 & 24 & 102 \\
\hline 6 & Maret & 2015 & 17 & 31 & 19 & 23 & 90 \\
\hline 7 & April & 2015 & 15 & 36 & 11 & 33 & 101 \\
\hline 8 & Mei & 2015 & 19 & 24 & 4 & 21 & 73 \\
\hline 9 & Juni & 2015 & 20 & 30 & 3 & 29 & 94 \\
\hline 10 & Juli & 2015 & 12 & 29 & 9 & 19 & 69 \\
\hline 11 & Agustus & 2015 & 16 & 22 & 2 & 19 & 59 \\
\hline 12 & September & 2015 & 27 & 44 & 19 & 33 & 124 \\
\hline
\end{tabular}

Sumber: Pengadilan Agama Watampone, 2015.

Berdasarkan data tabel 1, dari sekian kasus perceraian yang terjadi di Kabupaten Bone dapat perceraian di Kabupaten Bone sangat tinggi. Pada tiap bulannya tidak kurang dari angka lima puluh kasus bahkan sampai mencapai angka ratusan kasus perceraian. Berdasarkan tabel 1 dapat pula di lihat bahwa faktor penyebab terbesar terjadinya perceraian ada pada item meninggalkan dan terus menerus. Dalam kolom moral terdapat beberapa faktor-faktor terbesar yang mendominasi penyebab terjadinya perceraian yakni tidak adanya tanggung jawab. Sedangkan pada item terus-menerus faktor penyebab paling dominan adalah tidak adanya keharmonisan dalam rumah tangga.
Faktor Penyebab Terjadinya Perceraian Masyarakat di Kabupaten Bone Sulawesi Selatan.

Pada dasarnya suami diberi hak untuk mengakhiri pernikahannya melalui talak, demikian pula istri diberi hak mengakhiri rumah tangganya dengan suaminya dengan jalan khulu', hal ini jika kedua belah pihak sudah menemukan kebuntuan dalam memperbaiki keadaan rumah tangga pasangan suami istri tersebut. Alquran memberi solusi bahwa jika tidak mampu lagi hidup bersama dengan baik, maka jika berpisah hendaknya perpisahan kedua pasangan suami istri itu berpisah secara baik pula. (Qardhawi, 1999: 368). Adapun faktor penyabab terjadinya perceraian di Kabupaten Bone yaitu sebagai berikut: 


\section{Faktor Moral}

Faktor ini disebabkan oleh semakin banyaknya pasangan suami istri yang sering terjadi percekcokan karena karakter dari salah satu pasangan. Misalnya suami yang suka berkata kasar dan memberikan julukan yang sangat tidak etis kepada istri. Sementara istri tidak senang dengan hal tersebut. Demikian pula sebaliknya si istri terkadang tidak menghargai suami dan menginjakinjak harga diri suami. Karena itulah maka beberapa kasus perceraian terjadi. Faktor moral ini terdiri dari beberapa hal yaitu sebagai berikut:

\section{Poligami Tidak Sehat}

Praktik poligami Rasulullah saw. selalu dijadikan dalil pembenaran poligami bagi kebolehan poligami dalam masyarakat muslim. Masyarakat bersasumsi bahwa tujuan poligami Rasulullah saw sebagaimana yang dilakukan banyak orang yaitu untuk memenuhi tuntutan atau hasrat seksual. Padahal Rasulullah saw melakukan poligami dengan tujuan untuk mengangkat atau meningkatkan kedudukan perempuan. Padahal pada masa itu kedudukan perempuan atau janda sangat rendah di masyarakat. Selain itu Rasulullah saw juga membatasi jumlah istri dalam poligami.

Namun kenyataannya, di Kabupaten Bone terdapat pernikahan poligami yang tidak sehat. Sebagaimana diawali dengan tujuan pemenuhan hasrat seksual dan bukan berdasarkan tujuan untuk memberikan pengakuan sosial bagi perempuan ataupun janda. Sehingga setelah terjadi pernikahan selama beberapa waktu pihak wanita banyak yang mengajukan gugatan cerai. Karena sudah tidak mampu menjalani kehidupan poligami. Hal ini dilandasi oleh sikap ketidakadilan yang dilakukan oleh suami terhadap para madunya. Dengan demikian para istri merasa dizalimi oleh suaminya.

\section{Krisis moral}

Moral merupakan hal yang sangat penting dalam hal pergaulan manusia, moral inilah yang menjadi aturan dalam kehidupan baik masyarakat maupun lingkungan keluarga. Perceraian dengan motif krisis moral ini juga terjadi di Kabupaten Bone. Kasus seperti ini disebabkan oleh suami yang memiliki karakter yang buruk dan tidak ada niat unuk memperbaiki sikapnya. Sehingga istri tidak mampu bertahan dan mengajukan perceraian.

Karakter buruk yang ditunjukkan suami seperti memiliki kebiasaan minum minuman keras dan melakukan perjudian. Efek dari karakter yang buruk menyebabkan terjadinya dampak yang lebih luas terhadap keluarga seperti tidak ada tanggung jawab lagi kepada istri dan anak.

\section{Cemburu}

Cemburu merupakan hal yang lumrah dalam hubungan percintaan umat manusia. Sebagaimana kisah cemburunya istri Rasulullah saw, St. Aisyah terhadap istri pertama Rasulullah yakni St. Khadijah. Cemburu yang baik dapat meningkatkan keharmonisan dan tanggung jawab suami istri dalam keluarga. Sehingga wajar jika dikatakan bahwa cemburu adalah tanda cinta.

Namun cemburu yang berlebihan dapat mendatangkan bencana dalam sebuah hubungan pernikahan yakni cekcok antar suami istri, hilangnya kepercayaan terhadap pasangan bahkan bisa berakhir pada perceraian.

Dalam kasus perceraian di Kabupaten Bone juga ditemukan faktor yang menyebabkan terjadinya perceraian, yaitu kecemburuan. Adanya sikap kecemburuan baik oleh istri maupun suami terhadap pasangannya yang terjadi secara terus menerus tanpa adanya solusi menyebabkan salah satu pasngan mengajukan tuntutan cerai. Cemburu di sini dapat diartikan sebagai perasaan sudah tidak dipedulikan lagi karena adanya penyebab lain yang menjadi pengalih perhatian. Diantaranya adalah kehadiran pihak lain dalam sebuah hubungan pernikahan. Pihak lain yang dimaksud adalah wanita atau pria idaman lain, ataupun kecumburuan terhadap keluarga pasangan yakni kecemburuan terhadap orang tua pasangan (mertua).

\section{Faktor Meninggalkan}

Faktor ini biasanya didominasi oleh pihak lelaki yang tidak memiliki tanggung jawab kepada keluarga sehingga meninggalkan keluarga yang menjadi tanggungannya sehingga keluarga menjadi terlantar. Faktor meninggalkan ini di antaranya:

\section{Kawin paksa}

Sudah menjaditradisi di masyarakatBugis Bone, dimana para orang tua bertugas mencarikan jodoh terbaik untuk anak-anaknya. Hal ini merupakan hal yang terpuji yang dilakukan oleh orang tua sebagai bentuk tanggung jawabnya terhadap anaknya. Namun ada beberapa orang tua yang kemudian memaksakan kehendak terhadap anaknya dengan cara menjodohkan anak tersebut dengan keluarga ataupun orang lain yang mereka anggap layak untuk dijadikan menantu. Hal ini dilandasi sebagai bentuk kepercayaan orang tua terhadap pilihan yang telah ditetapkan untuk anak mereka. 
Namun jika hal ini tidak sejalan kehendak anak maka dapat muncul berbagai macam problem. Anak melakukan penolakan karena memiliki alasan tersendiri. Alasan yang biasanya dikemukakan oleh anak sebagai bentuk penolakan mengenai kawin paksa adalah masih ingin melanjutkan sekolah atau masih ingin bebas tanpa terikat oleh pernikahan atau si anak memiliki impian sendiri mengenai calon pasangannya. Dan kebanyakan yang menjadi korban praktek kawin paksa adalah perempuan yang tergolong memiliki usia muda. Hal ini Karena para orang tua menganggap bahwa anak perempuan masih lebih mudah untuk diatur dan mereka lebih penurut.

Seiring berjalannya waktu dalam sebuah pernikahan yang dipaksakan. Tidak sedikit kemudian pasangan yang bisa menjalani dan bisa menerima pernikahan tersebut, sehingga pernikahan ini kemudain bisa berjalan lama dan awet.

Namun tidak dapat pula dipungkiri bahwa pernikahan dengan dasar kawin paksa juga menimbulkan masalah. Masalah yang paling banyak muncul ada pada pihak yang dinikahkan. Mereka akan selalu mencari celah untuk mencari kesalahankesalahan. Setelah menjalani pernikahan tanpa dasar persetujuan, hal ini bisa menimbulkan cekcok antar pasangan. Hal ini menyebabkan terjadinya ketidakhamonisan dalam sebuah pernikahan. Tidak ada lagi sakinah dalam sebuah ikatan.

Dengan adanya masalah yang berlarut larut maka salah satu pihak kemudian mengadukan gugatan cerai. Perceraian yang terjadi tidak hanya memutuskan hubungan antar suami dan istri namun berdampak pula pada keluarga besar kedua pasangan.

\section{Ekonomi}

Kemapanan ekonomi merupakan salah satu penunjang berlangsungnya sebuah rumah tangga. Kemapanan ekonomi dalam sebuah rumah tangga bisa memberikan pengaruh terhadap keharmonisan rumah tangga. Pemenuhan kebutuhan bukan menjadi masalah lagi jika dalam sebuah rumah tangga memiliki ekonomi yang baik. Bahkan sebuah rumah tangga yang baik ekonomimya juga bisa memberikan pengaruh yang baik pada keluarga besar.

Sudah menjadi tanggung jawab seorang suami untuk memenuhi kebutuhan keluarganya. Dan sudah menjadi kewajiban bagi istri untuk mampu mengelola dan bertanggung jawab terhadap keuangan rumah tangga. Meski seorang suami berkewajiban untuk bekerja demi memenuhi kebutuhan ekonomi keluarga. Juga terdapat perempuan atau para istri yang juga aktif bekerja membantu suami. Hal ini masih bisa dilakukan selama ada kesepakatan antara dua belah pihak dan tidak terjadi kelalaian mengenai tanggung jawab masing-masing pihak.

Masalah kemudian dapat hadir jika dalam keluarga, kepala keluarga tidak dapat melakukan tanggung jawabnya untuk mencari nafkah. Namun hal ini dapat diatasi jika pihak istri tidak keberatan dan dapat membantu suami untuk mencari nafkah. Tetapi jika hal ini terus menerus berlangsung, dan pihak istri merasa memiliki peran ganda maka masalah ini bisa semakin meruncing dan menimbulkan konflik dalam rumah tangga.

Kasus perceraian yang ada di Kabupaten Bone didominasi oleh masalah ekonomi ini. Dari sekian kasus gugatan cerai oleh istri, masalah suami yang tidak bekerja dan tidak sanggup memberikan nafkah adalah dasar ajuan mereka. Ditambah adanya anak dan kehidupan yang mereka jalani masih menumpang di rumah keluarga semakin manambah masalah dalam hal ekonomi ini. Tidak adanya rumah pribadi baik yang dimiliki sendiri ataupun menyewa, kebutuhan anak yang semakin besar semakin bertambah, kebutuhan rumah tangga maupun kebutuhan pribadi istri yang tidak terpenuhi merupakan faktor masalah ekonomi yang terjadi dalam rumah tangga yang dapat memincu perceraian.

\section{Tidak Ada Tanggung Jawab}

Kasus perceraian yang ada di Kabupaten Bone mengenai tidak adanya tanggung jawab adalah faktor yang paling dominan yang dijadikan sebagai alasan terjadinya perceraian. Hal ini terjadi dikarenakan oleh faktor sebelumnya yang telah diuraikan di atas. Diantaranya adalah kawin paksa dan masalah ekonomi. Dalam ikatan suami istri yang dinikahkan karena kawin paksa menimbulkan dampak psikologis di diri pasangan nikah. Mereka merasa tidak nyaman untuk menjalani pernikahan sehingga untuk keluar dari masalah tersebut salah satu pasangan kemudian meninggalkan pasangannya tanpa ada informasi sebelumnya. Dengan demikian maka pihak yang meninggalkan tidak lagi dapat melaksanakan tanggung jawabnya sebagai suami atau isteri.

Hal lain yang menjadi dasar tidak adanya tanggung jawab adalah masalah ekonomi. Ekonomi 
yang buruk dalam rumah tangga mendorong salah satu pihak (suami) untuk segera memenuhi kebutuhan rumah tangganya dengan cara mencari pekerjaan yang lebih layak. Namun tingkat pendidikan yang rendah atau kurangnya pengalaman atau kreativitas yang dimiliki menyebabkan mereka kesulitan untuk mencari pekerjaan. Selain itu faktor gengsi yang menyebabkan seseorang juga tidak ingin mencari kerja yang asal-asalan. Hal yang demikian kemudian mendorong para suami untuk merantau ke daerah lain untuk mencari penghidupan yang lebih layak.

Dalam perantauan, terkadang seorang suami lupa atau tidak lagi menunaikan tanggung jawabnya terhadap anak atau istri yang ditinggalkan. Baik itu berupa tanngung jawab lahir maupun batin. Mereka tidak lagi melakukan kontak sekadar memberi kabar sehingga para isteri yang ditinggal tersebut tidak mengetahui apakah suami mereka masih hidup atau tidak. Bagi isteri yang tidak sanggup menjalani kehidupan yang tidak jelas atau menggantung ini, kemudian mengajukan gugatan cerai pada pengadilan.

Hal demikian pada akhirnya memberikan dampak bagi keluarga yang mengalami perceraian. Adapun dampaknya berupa: pertama dampak psikologi, setelah terjadi perceraian, maka isteri dan anaklah yang menjadi korban perceraian. Stigma negatif yang sering melekat pada janda membuat perempuan memiliki beban psikologi. Demikianpula dengan anak korban perceraian yang kehilangan figur ayah. Kedua dampak ekonomi, perempuan korban perceraian sedikit banyak akan mengalami problema ekonomi, apalagi mantan suami tidak memiliki tanggung jawab kepada anaknya. Sehingga kewajiban memberikan nafkah menjadi tanggung jawab ibu sebagai single parent. Ketiga dampak sosial, perempuan korban perceraian sering mendapat perlakuan yang tidak baik dari masyarakat, apalagi jika kasus perceraian disebabkan oleh faktor sosial misalnya sang istri tidak sanggup hidup dengan suami karena tidak mendapat nafkah batin atau suami cacat fisik. Maka perempuanlah yang sering dipersalahkan, masyarakat sering memberi sanksi sosial kepada mereka dengan menekan dengan menganggap mereka tidak setia.

Dari dampak yang muncul perlu dihadirkan beberapa solusi untuk menangani hal tersebut. Solusi yang diberikan yang terkait dengan permsalahan ekonomi guna menekan angka perceraian di Kabupaten Bone yaitu:

\section{Pembinaan Masyarakat tentang Tujuan Perkawinan dan Ekonomi Syariah}

Menurut Muhammad Abdul Manan Islamic economics is a social science which studies the economics problems of a people imbued with the values of Islam (Mannan, 1980: 3). Jadi, menurut Manan ilmu ekonomi Islam adalahilmu pengetahuan sosial yang mempelajari masalahmasalah ekonomi masyarakat yang diilhami oleh nilai-nilai Islam. Sedangkan Umer Chapra mendefinisikan bahwa Islamic economics was defined as that branch of knowledge which helps realize human well-being through an allocation and distribution of scarce resources that is in confinnity with Islamic teaching without unduly curbing Individual freedom or creating continued macroeconomic and ecological imbalances. Jadi, Menurut Chapra ekonomi Islam adalah sebuah pengetahuan yang membantu upaya realisasi kebahagiaan manusia melalui alokasi dan distribusi sumber daya yang terbatas yang berada dalam koridor yang mengacu pada pengajaran Islam tanpa memberikan kebebasan individu atau tanpa perilaku makro ekonomi yang berkesinambungan dan tanpa ketidakseimbangan lingkungan (Nasution dkk, 2006: 16). Demikian pula Menurut Syed Nawab Haider Naqvi, ilmu ekonomi Islam, singkatnya, merupakan kajian tentang perilaku ekonomi orang Islam representatif dalam masyarakat muslim modern (Lihat Naqvi, 2009: 28). Pembinaan tentang ekonomi syariah kepada masyarakat akan memberikan kesadaran untuk melakukan praktek ekonomi yang sesuai syariah dan tujuan perkawinan yang sesungguhnya.

Masyarakat Kabupaten Bone yang heterogen dari berbagai jenis suku dan memiliki latar pendidikan yang berbeda menjadi salah satu faktor yang menyebabkan masyarakat tidak memahami perkawinan dan tanggung jawab antara suami dan istri.

Banyak masyarakat yang belum memahami makna perkawinan. Tanggung jawab suami dalam keluarga, sehingga suami yang memiliki umur yang masih muda dan belum memahami tanggung jawabnya akan mengabaikan keluarga, bahkan yaang lebih parah tidak memberikan nafkah lahir dan batin. Sehingga tujuan perkawinan dan tujuan ekonomi syariah untuk menjadi keluarga sakinah, mawaddah dan warahmah tidak tercapai bahkan kehidupan rumah tangga jauh dari mashlahat. Jadi hal yang sangat penting dilakukan untuk menekan 
jumlah perceraian adalah memberikan pemahaman yang mendalam kepada kedua calon pengantin untuk memahami tanggung jawabnya sebagai suami dan sebagai istri dalam keluarga.

\section{Penanaman Nilai-Nilai Agama}

Agama adalah pondasi yang paling mendasar yang akan mengarahkan manusia pada kebaikan. Dengan penanaman nilai-nilai agama, maka efek buruk dari perilaku suami dan istri akan lebih diminimalisir. Suami yang memiliki karakter tempramen suka marah jika dilakukan penanaman agama, maka akan menekan amarahnya, dibanding dengan suami yang tidak memahami agama. Suami yang memiliki pemahaman agama yang baik akan menjadi imam yang baik bagi keluarga dan tidak mudah mengambil keputusan untuk bercerai karena memiliki pertimbangan yang lebih matang berdasarkan Alquran dan hadis. Demikian pula isteri yang memiliki pemahaman mendalam tentang agama, menganai posisinya sebagai isteri. Isteri memperlakukan diri sebagai mitra suami dan memahami tanggung jawab sebagai isteri. Memahami hak dan kewajibannya yang telah dijelaskan dalam Alquran dan hadis.

\section{Pemberian Persyaratan Kemapanan Ekonomi Sebelum Menikah}

Kehidupan rumah tangga setelah perkawinan tidak hanya sebatas memahami tanggung jawab suami isteri. Tetapi kemauan untuk melakukan tanggung jawab tersebut. Sebelum melakukan perkawinan calon pengantin diberikan persyarakatan. Lembaga perkawinan memberikan persyaratan kepada calon pengantin dalam hal umur. Calon pengantin harus memiliki batasan umur unuk bisa melakukan perkawinan. Hal ini dilakukan untuk melihat kematangan calon pengantin untuk memasuki kehidupan rumah tangga yang memiliki berbagai keadaaan yang harus mampu dipecahkan.

Persyaratan ini efektif untuk menekan jumlah perceraian karena pemikiran yang lebih matang mampu menyelesaikan masalah dengan baik dan tidak gegabah untuk memutuskan untuk bercerai. Namun hal yang tidak kalah pentingnya memahami tanggung jawab suami selaku kepala keluarga. Salah satu memberikan nafkah lahir dan batin. Faktor yang sangat mendominasi yang menjadi penyebab perceraian adalah meninggalkan karena faktor ekonomi.

Berdasarkan hasil penelitian yang dilakukan, banyak kasus perceraian yang terjadi karena suami tidak memberikan nafkah kepada isteri karena tidak memiliki pekerjaan tetap dan memiliki penghasilan yang tidak cukup untuk membiayaan kehidupan rumah tangga. Di samping itu masih banyak keluarga yang dibiayai oleh orang tua mereka masing-masing. Ini menunjukkan bahwa perkawinan seperti tidak didasari oleh pertimbangan yang baik dalam hal ekonomi. Kemapanan ekonomi calon pengantin menjadi hal yang sangat penting. Kebutuhan rumah tangga yang tidak mampu dicukupi suami akan menjadi awal konflik yang memicu terjadinya perceraian.

Di sisi lain kasus perceraian yang terjadi dalam hal ekonomi, setelah suami tidak mampu mencukupi kebutuhan keluarga, istri yang pada awalnya tidak memiliki penghasilan juga tidak mampu membantu ekonomi keluarga, sehingga masalah ekonomi ini akan berlaru-larut dan akhirnya menjadi pemicu konflik yang lain yang pada akhirnya menyebabkan perceraian.

Sebagai sebuah solusi menekan masalah ekonomi ini, persyaratan kemapanan ekonomi menjadi hal yang penting bagi kedua calon pengantin. Jika suami memiliki pekerjaan dan tanggung jawab yang besar untuk memenuhi kebutuhan hidup setelah pernikahan, maka kemungkinan untuk muncul konflik ekonomi dapat diminimalisir. Demikian juga sebaliknya jika isteri memiliki pekerjaan atau penghasilan akan mampu memberikan bantuan kepada suami, jika suami memiliki pekerjaan yang tetap namun masih belum mampu mencukupi kebutuhan keluarga, maka istrilah yang akan memberikan bantuan. Sehingga kemungkinan untuk muncul masalah ekonomi dapat diminimalisir.

\section{PENUTUP}

Berdasarkan pembahasan di atas, maka penulis mengemukakan beberapa kesimpulan dalam penelitian ini bahwa perceraian di Kabupaten Bone disebabkan oleh beberapa hal yaitu faktor moral, faktor suami atau istri meninggalkan pasangannya, menyakiti baik psikis maupun fisik dan konflik secara terus menerus dan tidak dapat terselesaikan. Dampak yang muncul dari perceraian ini meliputi dampak psikologis, dampak ekonomi dan dampak sosial. Problema ekonomi sangat berpengaruh terhadap peningkatan jumlah perceraian di Kabupaten Bone, hal ini disebabkan oleh pekerjaan suami isteri yang tidak tetap dan penghasilan yang tidak mampu memenuhi kebutuhan hidup akhirnya memunculkan konflik dalam keluarga yang berakhir pada perceraian. Sebagai solusi untuk menekan 
jumlah perceraian semua pihak akan berperan penting dalam pembinaan dan pemahaman ilmu-ilmu keagamaan, pengetahuan perceraian dan dampak yang timbul setelah perceraian dan memberikan syarat kemapanan ekonomi untuk calon pengantin agar mampu menekan jumlah perceraian karena motif ekonomi.

\section{UCAPAN TERIMAKASIH}

Ucapan terima kasih kepada seluruh pihak yang selama ini memberikan bantuan kepada peneliti hingga penelitian ini selesai yaitu Pihak Pengadilan Agama baik hakim, panitera, dan seluruh staf Pengadilan Agama Watampone sebagai informan dalam penelitian ini, yang telah memberikan informasi data perceraian dan motif di balik kasus perceraian masyarakat Bone. Para tokoh masyarakat yang berkompeten dan terkait dengan pembahasan penelitian baik dari ulama, masyarakat yang mengalami perceraian dan pemerintah. Masyarakat Kabupaten Bone yang diwakili oleh beberapa responden yang telah diobservasi dan dianalisis berkaitan dengan pembahasan penelitian ini. Secara khusus, kami menghaturkan terimakasih kepada Direktorat Jenderal Pendidikan Islam Kementerian Agama RI T.A. 2015, yang telah membiayai penelitian ini, juga kepada redaksi Jurnal Al-Qalam atas perkenannya menerbitkan tulisan ini. Jazakallah Khairan.

\section{DAFTAR PUSTAKA}

Abdul Aal, Khalid Assayyid. 2006. Seni Menumbuhkan Cinta. Surakarta: Ziyad Visi Media.

Ali, Zainuddin. 2007. Hukum Perdata Islam Di Indonesia. Jakarta: Sinar Grafika.

Al-Athar, Abd Nashr Taufik. 2000. Saat Anda Meminang, Terj. Abu Syarifah dan Afifah. Jakarta: Pustaka Azam.
Basyir, Ahmad Azar. 1995. "Hukum Perkawinan Islam", Skripsi. Fakultas Hukum Universitas Islam Indonesia Yogyakarta.

Ibrahim bin Abdullah, Muhammad. 2009. Ensiklopedi Islam Al-Kamil (Cet. V). Jakarta: Darus Sunnah.

Kamal, Abdul Malik. 2007. Fiqih Sunnah untuk Wanita, Jakarta: Al-I'tishom Cahaya Umat.

Kara, Muslimin. 2005. Bank Syariah Di Indonesia Analisis Terhadap Pemerintah Indonesia Terhadap Perbankan Syariah. Yogyakarta: UII Press.

Khon, Abdul Majid. 2009. Fikih Munakahat. Terj, Al Usyratu Ahkamuhaa Fii Tasyri'i Islam. Amzah, Jakarta.

Mannan, Muhammad Abdul. 1980. Islamic Economics, Theory and Practice. India: Idarah Adabiyah.

Naqvi. Syed Nawab Haider. 2009. Menggagas Ilmu Ekonomi Islam, terj. M. Saiful Anam dan Muhammad Ufuqul Mubin. Yogyakarta: Pustaka Pelajar.

Nasution, Edwin Mustafa dkk. 2006. Pengenalan EksklusifEkonomi Islam. Jakarta: kencana. Qardhawi.Yusuf. 1999. Fatawa Mu'ashirah Juz II. Manshurah: Darul Wafa. 2005. Markaz Al-Mar'ah fil hayah al-Islamiyah. Cairo: Maktabah Wahbah.

Sabiq, Sayyid. t.th. Fiqh Al-Sunnah (Jilid. II). Cairo: Maktabah Daru al-Turats.

Yuliadi, Imamudin. 2006. Ekonomi Islam. Yogyakarta: LPPI. 